\title{
Influencing Factors of Corporate Performance of Life Insurance Companies - Evidence from China
}

\author{
Maoguo $\mathrm{Wu}^{1} \&$ Yanyuan $\mathrm{Wang}^{1}$ \\ ${ }^{1}$ SHU-UTS SILC Business School, Shanghai University, China \\ Correspondence: Yanyuan Wang, SHU-UTS SILC Business School, Shanghai University, China
}

Received: April 1, 2018

Accepted: April 18, 2018

Online Published: April 23, 2018

doi:10.5430/afr.v7n2p219

URL: https://doi.org/10.5430/afr.v7n2p219

\begin{abstract}
At present, the life insurance industry in China is still in the initial stage of development, which is characterized by limited scale, low penetration rate and low intensity. However, the large population base, the proliferation of middle classes, and the continuously improving socio-economic environment in China imply underlying developmental opportunities for the life insurance industry. Gaps in state pension have appeared owing to the issue of aging population, which signals that insurance companies with commercial properties may become an integral part of resident endowment. Ever since 2014, Chinese government has implemented numerous policies that are beneficial to the life insurance industry, for instance, diversifying investment channels of premiums, allowing a certain proportion of premiums in risky investments, and removing the restriction that the rate of return on common stakeholders' equity (ROE) of participating insurance is capped at 5\%. This paper constructs a panel data of 36 Chinese life insurance companies from 2010 to 2014. A serial of preliminary tests are taken in order to avoid spurious regression. By dint of the fixed effect model and panel threshold model, the paper analyzes the relation between operation-related factors and the corporate performance of life insurance companies. According to empirical findings, bancassurance income rate, professional insurance agency income rate, participating insurance income rate, group insurance income rate, company scale and solvency adequacy ratio are negatively correlated with corporate performance. When life insurance companies are associated with banks in capitals, bancassurance income rate positively influences corporate performance. The paper also investigates the impact of specific marketing channel structure and product structure on corporate performance. Policy implications are proposed accordingly.
\end{abstract}

Keywords: Chinese life insurance companies, corporate performance, operational factors, fixed effect model, panel threshold model

\section{Introduction}

Life assurance is a contract between the policy holder and the insurer, where the insurer promises to pay lump-sum insurance proceeds to a predetermined beneficiary in exchange for a premium, upon survival or death of the insured. Life insurance is used to cope with economic burdens induced by accidental death of the insured as well as insufficient pensions when life span is beyond the expected range. Besides, life insurance possesses the characteristics of saving function, i.e., cash flows are refunded to the policy holder in a steady form.

The Chinese life insurance industry has developed rapidly but not matured yet. Statistics from Dagong Global Credit Rating show that compared with the insurance penetration rate of $6 \%$ to $12 \%$ in mature markets, at the end of 2012 penetration rate in China is only $2.9 \%$, among which the penetration rate of life assurance is only $1.7 \%$. Additionally, in China, insurance premium per capita as the density is only $\$ 179$, far less than the mature level of $\$ 2,000$ to $\$ 7,000$. Furthermore, life insurance companies constitute an important financial institution in a quasi-perfect competitive insurance market and the life insurance industry owns tremendous assets. In United States, total assets of the life insurance industry are at least comparable to or even exceeding that of banking. Nevertheless, total assets of the life insurance industry in China are approximately 10 trillion in 2014, which is roughly equivalent to $17 \%$ of total assets of the banking industry. Consequently, the Chinese life insurance industry has great potential.

The unique social environment and the constantly adjusting economic environment in China are the foundation of developing the life insurance industry. Attributed to residents' increased awareness of risk protection, China's population base, which is the largest in the world, could be converted into an enormous life insurance market. Currently, China is confronted with an aggravating trend of population aging, which results in shortage of pensions. 
Hence, insurance companies are highlighted in tackling such a dilemma. The economic prosperity, involving growth in GDP and disposable income as well as the emerging of the middle class, signifies stronger purchasing power and underlying demand for insurance, which gives impetus to the life insurance industry.

Chinese government has carried out plenty of dividend policies that create an open political environment for life insurance companies to operate in. The constraint that the maximum ROE of participating insurance is $2.5 \%$ has been slackened. Thus, the liberalization of interest rate can thoroughly change the homogenization of universal life insurance, making it possible to launch differentiated products. Apart from that, regulators further expand the scope of investment of life insurance companies. Funds were previously confined to low risk investment while high risk investment, such as stock and real estate, is available at present. Even though the proportion in high risk investment is limited, premiums can be operated in various patterns. It is predicted that the disparity in product design and premium management is prone to be more significant among different life insurance companies. Therefore, competition in the Chinese life insurance industry tends to be more intense.

The remaining part of this paper is organized as follows. Section 2 reviews related literature on corporate performance assessment of life insurance companies and how external environment, capital scale, marketing channels and other factors affect corporate performance. Section 3 is devoted to data and descriptive analysis of core variables. Empirical research based on fixed effect model and panel threshold model is presented in Section 4, in which the relation between operational factors and corporate performance is investigated. Section 5 concludes the paper and proposes policy implications for life insurance companies in China.

\section{Related Literature}

In general, corporate performance is measured by return on equity (ROE), return on asset (ROA) and earnings per share (EPS). As for the measurement of corporate performance of insurance companies, numerous measurements have been put forward. On the basis of factor analysis, Yu (2005) establishes a mechanism composed of 11 financial indices including ROA, premium proceeds ratio and compensation ratio, and evaluates the corporate performance of life insurance companies from the aspects of profitability, solvency and operating leverage. However, Shi and Zhao (2003) argue that in addition to financial index, core competence such as market exploitation, information absorbing, resources integration, and innovation should be taken into account when evaluating the corporate performance of life insurance companies.

A great deal of literature pertains to influencing factors of corporate performance of life insurance companies. Only a partial selection is mentioned here. Regarding to the external environment, Li (2007) points out that law enforcement, social development, informatization and economy are positively related to the corporate performance of the life insurance industry. According to Shen (2009), the dependency ratio of child care and elderly care, educational level of residents and social security expenditure have positive impacts on the income of the life insurance industry. Alhassan, Addisson and Asamoah (2015) find that industrial concentration and inflation rate are negatively associated with the corporate performance of the life insurance industry.

In terms of factors relevant to capitals, Kweh et al. (2014) and Kou (2011) point out that the performance of domestic life insurance companies surpasses that of joint-venture companies and foreign invested life insurance companies. The government shareholding is in favor of corporate performance whereas executive shareholding and ownership concentration are negative factors influencing corporate performance (Wang and Peng, 2011). Jiang and Chen (2015) find that corporate capital scale has a positive relation to the corporate performance of life insurance companies. The finding tallies with the efficiency structure (ES) hypothesis. However, the market share is not significantly related to corporate performance, and this does not conform to the market power (MP) hypothesis.

Regarding marketing channels, Hu (2011) expounds that bancassurance in China has certain drawbacks, such as conflicts of interests between banks and life insurance companies and a high level of product homogeneity. Fan and Cheng (2009) verify that individual agency is more profitable than bancassurance. Nevertheless, owing to low efficiency and unsustainability, income of individual agents in China is lower than that of other channels, and individual agent channel suffers from the brain drain a lot (Mckinsey \& Company, 2012). Wassink, Castagnetta and Metz (2015) hold that individual agents, bancassurance and professional insurance agencies are in a gradual recession, which means that life insurance companies should develop pluralistic digital marketing.

\section{Data}

This paper selects the top 40 life assurance companies in China according to premiums, and removes companies whose equity has undergone conspicuous changes and companies with imputed data. Ultimately, data of 36 life insurance companies, including $5 \mathrm{~A}$-share or $\mathrm{H}$-share listed insurance companies, are chosen. In terms of premiums, 
the market share of the sample from 2010 to 2014 is $96.2 \%, 97.92 \%, 96.95 \%, 94.46 \%$ and $91.95 \%$, respectively. Data of solvency adequacy ratio are gathered from the annual disclosure of each life assurance company, and other data are gathered from China Insurance Yearbook.

\subsection{Corporate Performance and Income Structure}

The ROE of life insurance companies in China is unfavorable given that the mean is $-3.18 \%$. The standard deviation of ROE is up to 25.5, which implies that the distribution of ROE is dispersive and there is polarization in the life insurance industry. Premium income rate has a mean of $79.74 \%$ and a standard deviation of 49.78 , indicating that $80 \%$ of income is from premiums directly whereas the rest comes from operating investment of premiums. Thus, income structure in the Chinese life insurance industry is reasonable.

\subsection{Marketing Channel Structure}

Figure 1 displays the marketing channel structure of the Chinese life insurance industry. In the past 5 years, bancassurance income rate has decreased from $53.5 \%$ to $37.2 \%$ while individual agent income rate has increased to $51.6 \%$. Hence, individual agent has turned into the most important marketing channel. The income rate of direct selling, including online sales and telemarketing has nearly doubled from $5 \%$ to $9.4 \%$. Considering professional agency, brokerage business and other channels, the income rate has maintained at a relatively low level for the last 5 years. As for channel concentration ratio, the mean is $68.24 \%$, which illustrates that life insurance companies in China overly depend on one specific channel. The standard deviation of 19.18 reflects that life assurance companies differ greatly in channel concentration.

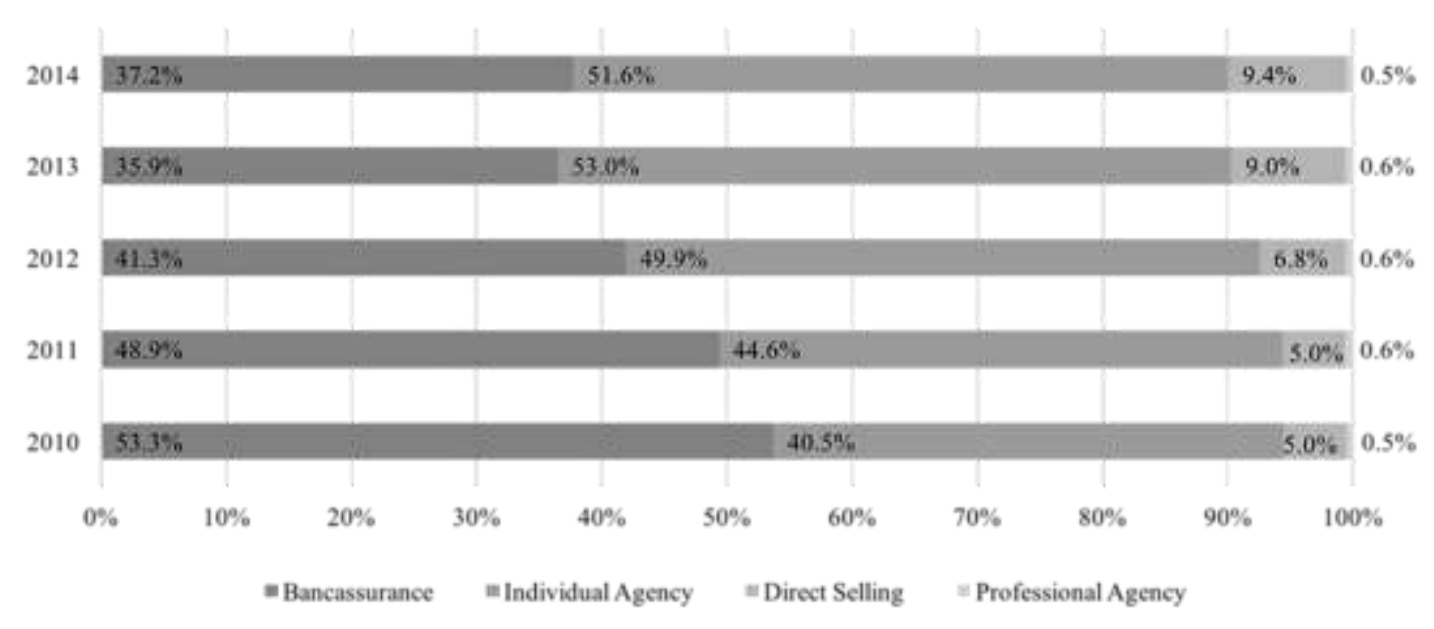

Figure 1. Income Rate Percentage by Marketing Channel

\subsection{Product and Compensation Rate}

As shown in Figure 2, it is apparent that product structure of the life assurance industry in China has experienced tremendous changes since 2010. In 2014, traditional insurance surged to $38.6 \%$. By contrast, participating insurance that once occupied a leading position as of 2013 plunged to $59.7 \%$. Group insurance, unit-linked insurance and universal insurance have sustained a tiny market share. In addition, product concentration plummeted in 2014 , when previously it was in a level out above $85 \%$. 


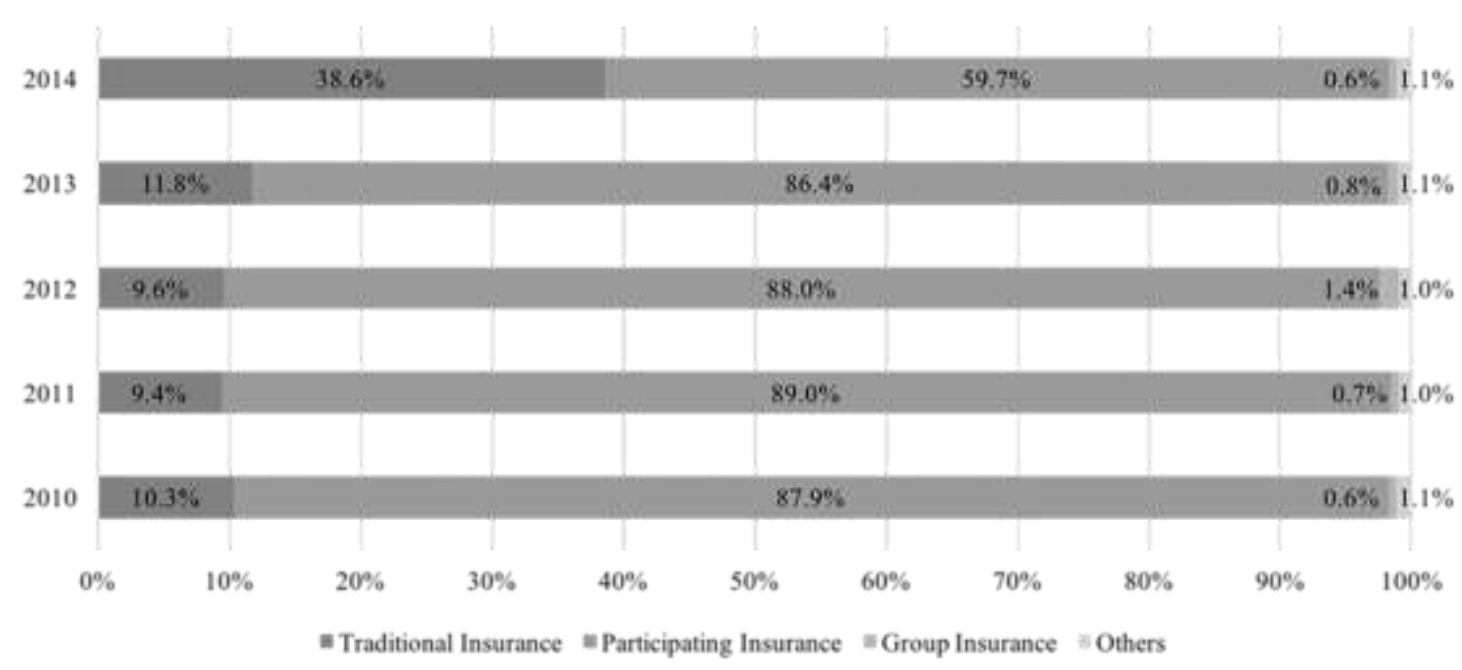

Figure 2. Income Rate Percentage by Product

The reimbursement of the life insurance industry in China is comparatively less in comparison to that of mature markets where the compensation rate exceeds $60 \%$. In the sample, the compensation rate has a mean of $13.07 \%$, a standard deviation of 14 and a maximum of $66 \%$. In fact, over half of life insurance companies in China have a compensation rate less than $10 \%$. It is a minority of companies that offer relatively sufficient reimbursement to clients that pull up the overall level.

\subsection{Human Resources}

The average number of salesmen of sample life insurance companies is 70,359 and the standard deviation is 154,240. It shows that the disparity in the scale of salesmen among life insurance companies is in evidence. China Life Property \& Casualty Insurance Co., Ltd. (China Life) has the most marketing personnel of more than 743 thousand. However, quite a few companies with small scale whose major business is bancassurance and professional insurance agency have not built a marketing team yet. Given that the rate of staff with an undergraduate degree or above has a mean of $46.23 \%$, insurance personnel in China are of relative high qualification. Specifically, PICC Life Insurance Co., Ltd., a remarkable company in the industry, has the minimum rate of $7.26 \%$ while that of some small-scale foreign invested life insurance companies is up to $70 \%$. As a consequence, the diathesis of personnel is not significantly correlated with corporate performance.

\subsection{Market Share and Corporate Scale}

The market share of the sample has a mean of $2.65 \%$ and a standard deviation of 5.82, among which the top 7 life insurance companies hold over $80 \%$ and China Life with the largest scale accounts for more than $30 \%$. Such a market structure indicates that the Chinese life insurance industry is an oligopoly market. Average assets of life assurance companies in China are 15.1 billion, but it has a standard deviation of 358. Hence, participants in the life insurance industry in China have vastly different market power and influence.

\subsection{Risk Control}

The China Insurance Regulatory Commission (CIRC) stipulates that solvency adequacy ratio as the indicator of risks should exceed $100 \%$. As for the sample, the solvency adequacy ratio has a mean of $3274.199 \%$ and a standard deviation of 33706. Small businesses that have just entered the market possess high solvency in virtue of no need for debt redemption, thereby, elevating the average level. In contrast to mature markets with an average ratio of $150 \%$ to $500 \%$, life insurance companies in China are short in solvency capability.

\section{Empirical Analysis}

\subsection{Hypotheses}

Following previous literature, this paper proposes 11 hypotheses on the relation between operational factors and the corporate performance of life insurance companies in China.

- Hypothesis A: Premium income rate is positively related to corporate performance

- Hypothesis B: Bancassurance income rate is negatively related to corporate performance 
- Hypothesis C: For life insurance companies associated with banks in capitals, bancassurance income rate is positively related to corporate performance

- Hypothesis D: Professional insurance agency income rate is negatively related to corporate performance

- Hypothesis E: Percentage of personnel with undergraduate degree or above is positively related to corporate performance

- Hypothesis F: Market share is positively related to corporate performance

- Hypothesis G: Number of salesmen is positively related to corporate performance

- Hypothesis H: Participating insurance rate is negatively related to corporate performance

- Hypothesis I: Group insurance rate is negatively related to corporate performance

- Hypothesis $\mathrm{J}$ : Corporate scale is positively related to corporate performance

- Hypothesis K: Solvency adequacy ratio is positively related to corporate performance

ROE, the ratio of net income over average stakeholders' equity, is the dependent variable. It is calculated as follows:

$$
\text { ROE }=\text { net income/average stakeholders' equity, }
$$

where average stakeholder's equity is the average of the beginning balance and the end balance.

The paper selects 11 explanatory variables according to hypotheses above. Particularly, if a life insurance companies is a subsidiary of a bank, for instance, Hong Kong and Shanghai Banking Co., Ltd. (HSBC) and HSBC Life Insurance, or a life insurance companies and a bank are affiliated to the same conglomerate, for instance, Ping An Life insurance companies of China Co., Ltd. and Ping An Bank Co., Ltd., then the life insurance companies is treated as possessing certain control over the bank. An interaction term (HOST.BANCA) combining bancassurance income rate (BANCA) and a dummy variable (HOST) is constructed to denote bancassurance income rate for life insurance companies associated with banks in capitals.

The implication of the explained variable and all explanatory variables is summarized in Table 1.

Table 1. Summary of Variables

\begin{tabular}{|c|c|c|}
\hline Variable & Abbreviation & Meaning \\
\hline $\begin{array}{l}\text { Rate of Return on Common Stakeholder' } \\
\text { Equity }\end{array}$ & ROE & Net Income over Average Stakeholders' Equity \\
\hline Premium Income Rate & OPERATION & Premium Income as Percentage of Corporate Income \\
\hline Bancassurance Income Rate & BANCA & $\begin{array}{l}\text { Bancassurance Income as Percentage of Premium } \\
\text { Income }\end{array}$ \\
\hline $\begin{array}{l}\text { Bancassurance Income Rate for Insurance } \\
\text { Companies Associated with Banks in } \\
\text { Capitals }\end{array}$ & HOSTBANCA & $\begin{array}{l}\text { Bancassurance Income for Insurance Companies } \\
\text { Associated with Banks in Capitals as Percentage of } \\
\text { Premium Income }\end{array}$ \\
\hline $\begin{array}{l}\text { Professional Insurance Agency Income } \\
\text { Rate }\end{array}$ & PROAGENT & $\begin{array}{l}\text { Professional Insurance Agency Income as Percentage } \\
\text { of Premium Income }\end{array}$ \\
\hline $\begin{array}{l}\text { Rate of Personnel with Undergraduate } \\
\text { Degree or above }\end{array}$ & EDU & $\begin{array}{l}\text { Personnel with Undergraduate Degree or above as } \\
\text { Percentage of Total Personnel }\end{array}$ \\
\hline Market Share & MKT & $\begin{array}{l}\text { Premium Income as Percentage of Industry's Total } \\
\text { Income }\end{array}$ \\
\hline Number of Salesmen & SALESMAN & Number of Salesmen (in thousands) \\
\hline Participating Insurance Income Rate & SAVING & $\begin{array}{l}\text { Participating Insurance Income as Percentage of } \\
\text { Premium Income }\end{array}$ \\
\hline Group Insurance Income Rate & GROUP & $\begin{array}{l}\text { Group Insurance Income as Percentage of Premium } \\
\text { Income }\end{array}$ \\
\hline Corporate Scale & SIZE & Company’s Total Assets \\
\hline Solvency Adequacy Ratio & SMF & Real Assets over Minimum Assets \\
\hline
\end{tabular}




\subsection{Impacts of Operational Factors on Corporate Performance}

In order to avoid spurious regression, a series of preliminary tests are taken first. Augmented Dickey-Fuller (ADF) test is conducted on the explained variable and all 11 explanatory variables. No unit root is found in any variable series, which implies that all variables are stationary. Hence, cointegration test is not performed.

As for regression model selection, the paper compares three alternative regression models, i.e., Ordinary Least Square (OLS), fixed effect, and random effect. Table 2 shows the test result of Breusch-Pagan Lagrange Multiplier test.

$$
\operatorname{eps}\left[\mathrm{i}_{\mathrm{d}}, \mathrm{t}\right]=\mathrm{X}_{\mathrm{b}}+\left[\mathrm{i}_{\mathrm{d}}\right]+\mathrm{e}\left[\mathrm{i}_{\mathrm{d}}, \mathrm{t}\right] .
$$

Table 2. Breusch-Pagan Lagrange Multiplier Test Results

\begin{tabular}{ccc}
\hline & Variance & Standard Deviation \\
\hline Return on Equity (ROE) & 650.5631 & 25.50614 \\
e & 266.6614 & 16.32977 \\
$\mu$ & 250.9983 & 15.84293
\end{tabular}

Null Hypothesis: The variance of $\mu$ is 0 .

$$
\text { chibar2 }(01)=64.39
$$

Prob $>$ chibar $2=0.0000$

Given that the p-value is less than 0.05 and the variance of $\mu$ is not equal to 0 , random effect model is superior to OLS. F test finds that fixed effect model outperforms OLS. Hausman test compares fixed effect model with random effect model. The test result is given in Table 3.

Table 3. Hausman Test Results

\section{Coefficient}

Variable

(b)

(B)

(b-B)

Square Root of

\begin{tabular}{ccccc} 
& Fixed Effect & Random Effect & Difference & Diag(V_b-V_B) \\
\hline HOSTBANCA & 0.6950194 & 0.1399118 & 0.5551077 & 0.335742 \\
OPERATION & -0.0147517 & -0.0096972 & -0.0050546 & 0.0022707 \\
PROAGENT & -1.6288 & -0.852128 & -0.7766718 & 0.5163194 \\
BANCA & -0.3650779 & -0.2929336 & -0.0721443 & 0.0869353 \\
SALESMAN & 0.0635422 & 0.0746629 & -0.0111206 & 0.0619746 \\
EDU & -0.1181158 & -0.042997 & -0.0751188 & 0.0609929 \\
MKT & -0.7470281 & 0.6587093 & -1.405737 & 1.814139 \\
SAVING & -0.347892 & -0.3114237 & -0.0364683 & 0.0282165 \\
GROUP & -0.4484757 & -0.4207899 & -0.0276858 & 0.0847771 \\
SIZE & -0.0036203 & -0.0031022 & -0.0005181 & 0.0009921 \\
SMF & -0.000082 & -0.0000463 & -0.0000357 & 0.0000273 \\
\hline
\end{tabular}

$$
\operatorname{chi} 2(9)=(b-B)^{\prime}\left[\frac{1}{\left(V_{-} b-V_{-} B\right)}\right](b-B)=-19.27 .
$$

chi2 is found to be negative. Thus, the coefficient difference is systematic. Fixed effect model is superior to random effect model.

Since the life insurance industry in China resembles an oligopoly, business practices of oligarchs affect the whole market, eventually leading to a high correlation among operational factors and corporate performance. Such 
phenomenon is probably accompanied with spurious regression. Hence, cross-section correlation test is carried out to judge whether cross-section correlation exists among different cross sections. Pesaran test and Friedman test are applied to delve into the existence of cross-section correlation. The test result is shown in Table 4.

Table 4. Pesaran Test and Friedman Test Results

\begin{tabular}{cc}
\hline Pesaran Test & Friedman Method \\
\hline $\mathrm{F}(1,96)=0.926$ & $\mathrm{~F}(1,96)=7.711$ \\
Prob $=0.3546$ & Prob $=1.000$ \\
\hline
\end{tabular}

The two p-values are both larger than 0.05 . Thereby, no cross-section correlation exists in the sample.

Panel data set, more often than not, is endogenous, implying that the causal effect between the explained variable and explanatory variables is ambiguous due to omission or measurement error of explanatory variables. Davidson-MacKinnon test is performed to examine endogeneity. In Davidson-MacKinnon test, instrumental variables that substitute explanatory variables should meet the following requirements: high correlation with the instrumented variable; no correlation with the stochastic error; no correlation with other explanatory variables. Hence, taking lag 1 of each explanatory variable as the instrument variable, Davidson-MacKinnon test finds that p-values of all variables exceed 0.05 . Therefore, all explanatory variables are concluded to be exogenous.

Homoskedasticity is one of the fundamental hypotheses of fixed effect model, which implies that variance of the stochastic error is a constant. Wald test is carried out for homoskedasticity test. The test result is presented in Table 5.

Table 5. Wald Test Results

Null Hypothesis: Random disturbance is homoscedastic.
\[ \begin{array}{c}\text { chi2 }(36)=3.0 \mathrm{e}+05 \\ \text { Prob }>\text { chi2 } 2=0.0000\end{array} \]

Wald test shows that the p-value is larger than 0.05 . Hence, strong presence of heteroskedasticity exists in the panel data set.

In summary, fixed effect model is found to be superior to OLS and random effect model in this case. Besides, there is heteroskedasticity, but no cross-section correlation or endogeneity. Therefore, fixed effect model that controls heteroscedasticity is deemed to be the most appropriate regression model. The regression function, ideally, would be of the following form.

$$
\begin{gathered}
\text { ROE }=\alpha+\beta_{1} \text { OPERATION }+\beta_{2} \text { HOSTBANCA }+\beta_{3} \text { BANCA }+\beta_{4} \text { PROAGENT } \\
+\beta_{5} \text { MKT }+\beta_{6} \text { EDU }+\beta_{7} \text { SALESMAN }+\beta_{8} \text { SAVING }+\beta_{9} \text { GROUP } \\
+\beta_{10} S I Z E+\beta_{11} \text { SMF }+\varepsilon
\end{gathered}
$$

where $\alpha$ is the intercept, $\beta_{\mathrm{i}}(\mathrm{i}=1,2,3, \ldots 9,10,11)$ is the regression coefficient, and $\varepsilon$ is the random error.

Table 6 presents regression results and robustness check. Regression 1 is OLS that controls heteroskedasticity; Regression 2 is fixed effect model that controls heteroskedasticity; Regression 3 is pooled OLS; Regression 4 is asymptotic fixed effect model; Regression 5 is panel corrected standard error model. 
Table 6. Regression Results and Robustness Check

\begin{tabular}{|c|c|c|c|c|c|}
\hline \multirow{2}{*}{$\begin{array}{l}\text { Explanatory } \\
\text { Variables }\end{array}$} & \multicolumn{5}{|c|}{ Explained Variable: ROE } \\
\hline & Reg. 1 & Reg. 2 & Reg. 3 & Reg. 4 & Reg. 5 \\
\hline \multirow{2}{*}{ OPERATION } & 0.0195 & -0.0148 & 0.0195 & -0.0148 & 0.0195 \\
\hline & $(-0.97)$ & $(-0.89)$ & $(-0.92)$ & $(-1.32)$ & $(-0.37)$ \\
\hline \multirow{2}{*}{ BANCA } & $-0.325^{* * *}$ & $-0.365^{* * *}$ & $-0.325^{* *}$ & $-0.365^{* * *}$ & $-0.325^{* * *}$ \\
\hline & $(-4.19)$ & $(-3.04)$ & $(-5.21)$ & $(-7.34)$ & $(-5.11)$ \\
\hline \multirow{2}{*}{ HOSTBANCA } & 0.0778 & $0.695^{* *}$ & $0.0778^{* *}$ & $0.695^{* * *}$ & $0.0778^{* * *}$ \\
\hline & $(-1.14)$ & $(-2.18)$ & $(-3.99)$ & $(-14.62)$ & $(-2.67)$ \\
\hline \multirow{2}{*}{ PROAGENT } & $-0.620^{* * *}$ & $-1.629^{* * * *}$ & $-0.620^{* * *}$ & $-1.629^{* * *}$ & $-0.620^{* * *}$ \\
\hline & $(-3.68)$ & $(-4.47)$ & $(-9.98)$ & $(-6.96)$ & $(-6.07)$ \\
\hline \multirow{2}{*}{ SALESMAN } & $0.0760^{* * *}$ & 0.0635 & $0.0760^{* * *}$ & $0.0635^{*}$ & $0.0760^{* * *}$ \\
\hline & $(-3.39)$ & $(-1.26)$ & $(-22)$ & $(-2.74)$ & $(-4.62)$ \\
\hline \multirow{2}{*}{ EDU } & 0.0504 & -0.118 & 0.0504 & $-0.118^{* *}$ & 0.0504 \\
\hline & $-0.78)$ & $(-1.41)$ & $-1.83)$ & $(-4.27)$ & $-0.95)$ \\
\hline \multirow{2}{*}{ MKT } & $1.437^{*}$ & -0.747 & $1.437^{* * *}$ & -0.747 & $1.437^{* *}$ \\
\hline & $(-1.7)$ & $(-0.67)$ & $(-5.67)$ & $(-0.64)$ & $(-2.36)$ \\
\hline \multirow{2}{*}{ SAVING } & $-0.244^{* *}$ & $-0.348^{* * *}$ & $-0.244^{*}$ & $-0.348^{* * *}$ & $-0.244^{* * *}$ \\
\hline & $(-2.53)$ & $(-3.68)$ & $(-2.88)$ & $(-9.14)$ & $(-3.18)$ \\
\hline \multirow{2}{*}{ GROUP } & $-0.431^{* * *}$ & $-0.448^{* * *}$ & $-0.431^{* *}$ & $-0.448^{* * *}$ & $-0.431^{* * *}$ \\
\hline & $(-3.25)$ & $(-4.54)$ & $(-4.44)$ & $(-9.67)$ & $(-5.34)$ \\
\hline \multirow{2}{*}{ SIZE } & $-0.00435^{* * *}$ & $-0.00362^{* * *}$ & $-0.00435^{* * *}$ & $-0.00362^{* * *}$ & $-0.00435^{* * *}$ \\
\hline & $(-3.55)$ & $(-2.99)$ & $(-6.12)$ & $(-5.41)$ & $(-3.37)$ \\
\hline \multirow{2}{*}{ SMF } & 0.00000443 & $-0.0000820^{* * * *}$ & 0.00000443 & $-0.0000820^{* * *}$ & 0.00000443 \\
\hline & $(-0.23)$ & $(-3.15)$ & $(-1.01)$ & $(-4.79)$ & $(-0.1)$ \\
\hline \multirow{2}{*}{ _CONS } & $30.58^{* * * *}$ & $56.20^{* * *}$ & $30.58^{* *}$ & $56.20^{* * *}$ & $30.58^{* * * *}$ \\
\hline & $(-3.65)$ & $(-3.9)$ & $(-5.23)$ & $(-10.99)$ & $(-4.13)$ \\
\hline $\mathrm{R}^{2}$ & 0.2597 & 0.2233 & 0.2597 & 0.2233 & 0.2597 \\
\hline
\end{tabular}

Note: $* * *, * *$ and $*$ denote that the variable is significant at $1 \%, 5 \%$ and $10 \%$ significance level, respectively.

Referring to Regression 2, fixed effect model that controls heteroscedasticity, the following conclusions can be drawn.

- The relation between premium income rate and ROE is insignificant.

- $\quad$ Bancassurance income rate is significantly negatively related to ROE at $1 \%$ significance level, which implies that in China, bancassurance is not a marketing channel with high efficiency. Thus, marketing investment and agency expenditure cannot attain equivalent return and profit.

- When life insurance companies are linked with banks in terms of capitals, bancassurance income rate is significantly positively related to ROE at 5\% significance level. Given that life insurance companies and banks are mutual stakeholders, the latter have the initiative to promote insurance for the former.

- $\quad$ Professional insurance agency income rate is significantly negatively related to ROE at $1 \%$ significance level. As long as professional insurance agency cooperates with multiple life insurance companies simultaneously, it is practically impossible for the agency to concentrate on selling products for one company.

- The number of salesman is positively related to ROE, but not significant, indicating that it is not recommended to recruit more marketing personnel in order to strengthen marketing competence.

- The percentage of personnel with undergraduate degree or above is negatively related to ROE, but not significant. The reason for the negative relation is that in years with large demand for insurance, life insurance companies are prone to hire massive temporary salesmen who only have qualification beneath the bachelor's degree level. 
- Market share is negatively related to ROE, but not significant, which verifies that the market power (MP) hypothesis and the efficiency structure (ES) hypothesis are not applicable to the life insurance industry in China.

- Participating insurance income rate is significantly negatively related to ROE at $1 \%$ significance level. The features of participating insurance, involving low rate of return, low security and analogous functions to other types of financial products, illustrate that Chinese life insurance companies cannot treat participating insurance as the principal income stream.

- The income rate of group insurance is significantly negatively related to ROE at $1 \%$ significance level, reflecting that in the circumstance of inadequate market perception as well as policy support, group insurance is not a channel that effectively generates proceeds.

- Corporate scale is significantly negatively related to ROE at $1 \%$ significance level. Therefore, expanding the size of life assurance companies is not necessarily beneficial to corporate performance.

- Solvency adequacy ratio is significantly negatively related to ROE at $1 \%$ significance level. When a life insurance company has just entered the market, there is no liability. Thereby, solvency is at a high level. At the same time, startup scarcely gains profits, naturally resulting in a low ROE. Hence, the phenomenon that solvency is in negative correlation with corporate performance consequently appears. In addition, a high solvency adequacy ratio maintaining in the long term implies that the company tends to possess abundant idle capitals.

\subsection{Impacts of Compensation Ratio on Corporate Performance}

This paper selects compensation ratio (COMP), which is compensation expenditure over premium income, as an additional explanatory variable, and delves into its impacts on corporate performance of life insurance companies. As for reimbursement, it is not the case that the less, the better. Low level of reimbursement certainly leads to abatement of compensation expenditure, eventually creating more profits for life insurance companies. Nevertheless, if a company intentionally depresses its compensation rate, the likelihood that customers receiving settlement of claim might decline, or the amount of insurance indemnity might shrink. As a result, customers' willingness to pay may slump considerably.

Under such context, this paper assumes that there exist one or more thresholds. At low levels, compensation rate is negatively related with corporate performance, but once the compensation rate exceeds a specific threshold, negative impacts emerge.

The prerequisites of panel threshold model are that all variables are stationary and the key threshold variable is exogenous. Hence, similar preliminary tests as in Section 4.2 are performed for unit root test and endogeneity test on compensation rate. Test results show that compensation rate, as the threshold variable, is stationary and exogenous, which implies that panel threshold model can be applied.

Prior to applying panel threshold model, firstly, it is of importance to examine whether there is panel effect or not, and subsequently, judge the quantity of thresholds and compute threshold values. Bootstrap (BS) check is adopted to test threshold effect. Test results are summarized in Table 8.

Table 8. Bootstrap Check of Threshold Effect

\begin{tabular}{ccccccc}
\hline \multirow{2}{*}{ Panel Threshold Model } & \multirow{2}{*}{ F-value } & \multirow{2}{*}{ p-value } & \multirow{2}{*}{ Times of BS } & \multicolumn{3}{c}{ Critical Value } \\
& & & & $1 \%$ & $5 \%$ & $10 \%$ \\
\hline Single Threshold & $5.451^{* *}$ & 0.047 & 300 & 9.604 & 4.959 & 3.761 \\
Double Threshold & $6.909^{* *}$ & 0.037 & 300 & 11.351 & 5.472 & 3.377 \\
Triple Threshold & 0 & 0.103 & 300 & 0 & 0 & 0 \\
\hline
\end{tabular}

Note: $* * *, * *$ and $*$ denote that the variable is significant at $1 \%, 5 \%$ and $10 \%$ significance level, respectively.

As presented in the table above, the p-values of bootstrap check for the single threshold model and the double threshold model are both less than 0.05 , indicating that both are statistically significant at $5 \%$ significance level. Nevertheless, the p-value of the triple threshold model is greater than 0.05 . Consequently, the sample data set only has two thresholds.

After confirming the existence of threshold effect for the compensation rate, threshold values are calculated and relevant tests are performed. At 5\% significance level, the critical value of likelihood ratio (LR) statistics is 7.35. In double threshold model, the value of the first threshold is $2.503 \%$ with a confidence interval of [2.32, 4.13], while the value of the second threshold is $4.61 \%$ with a confidence interval of [0.503, 66.79]. The regression function of the panel threshold model is as follows: 


$$
\begin{array}{r}
R O E=\alpha+\beta_{1} * I * \operatorname{COMP}\left(\operatorname{COMP} \leq \gamma_{1}\right)+\beta_{2} * I * \operatorname{COMP}\left(\gamma_{1} \leq \operatorname{COMP} \leq \gamma_{2}\right) \\
+\beta_{3} * I * \operatorname{COMP}\left(\operatorname{COMP} \geq \gamma_{2}\right)+\beta_{4} \text { OPERATION }+\beta_{5} H O S T B A N C A \\
+\beta_{6} \text { BANCA }+\beta_{7} \text { PROAGENT }+\beta_{8} M K T+\beta_{9} E D U
\end{array}
$$

where $\alpha$ is the intercept, $\beta_{i}(i=1,2,3, \ldots 12,13,14)$ is the regression coefficient, $\varepsilon$ is the random error, $\gamma_{i}(i=$ $1,2)$ is the threshold value, I is a dummy variable that is equal to 1 if pertinent conditions hold. Otherwise, it is equal to 0 .

Table 9 presents regression results and robustness check. Specifically, Regression 1 is double threshold panel model; Regression 2 is fixed effect model that controls heteroskedasticity with compensation rate per se as an additional explanatory variable, while Regression 3 is fixed effect model that controls heteroskedasticity with the quadratic term of compensation rate as an additional explanatory variable.

Table 9. Regression Results and Robustness Check

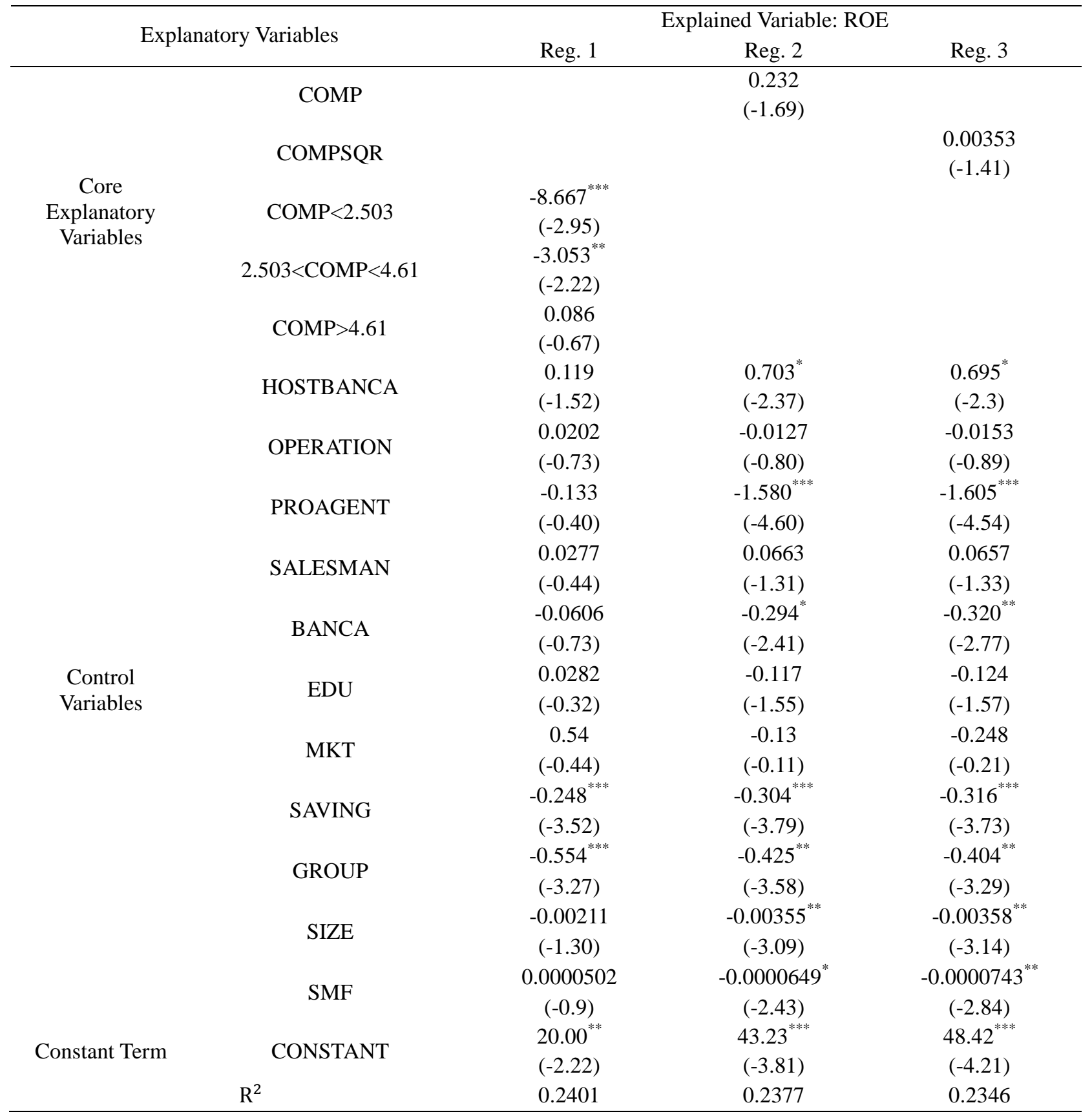

Note: $* * *, * *$ and $*$ denote that the variable is significant at $1 \%, 5 \%$ and $10 \%$ significance level, respectively. 
The goodness of fit of the double threshold model is 0.2401 , slightly higher than that of the multiple linear regression model (Regression 2) and that of the quadratic function model (Regression 3). Meanwhile, the coefficient of compensation rate is the most significant one in the double threshold model. Thus, it is justified to interpret the relation between reimbursement and ROE with the double threshold model. Such relation is rather analogues to the form of piecewise linear function. Two threshold values of the compensation rate divide that relation into 3 intervals, which is illustrated in Figure 3.

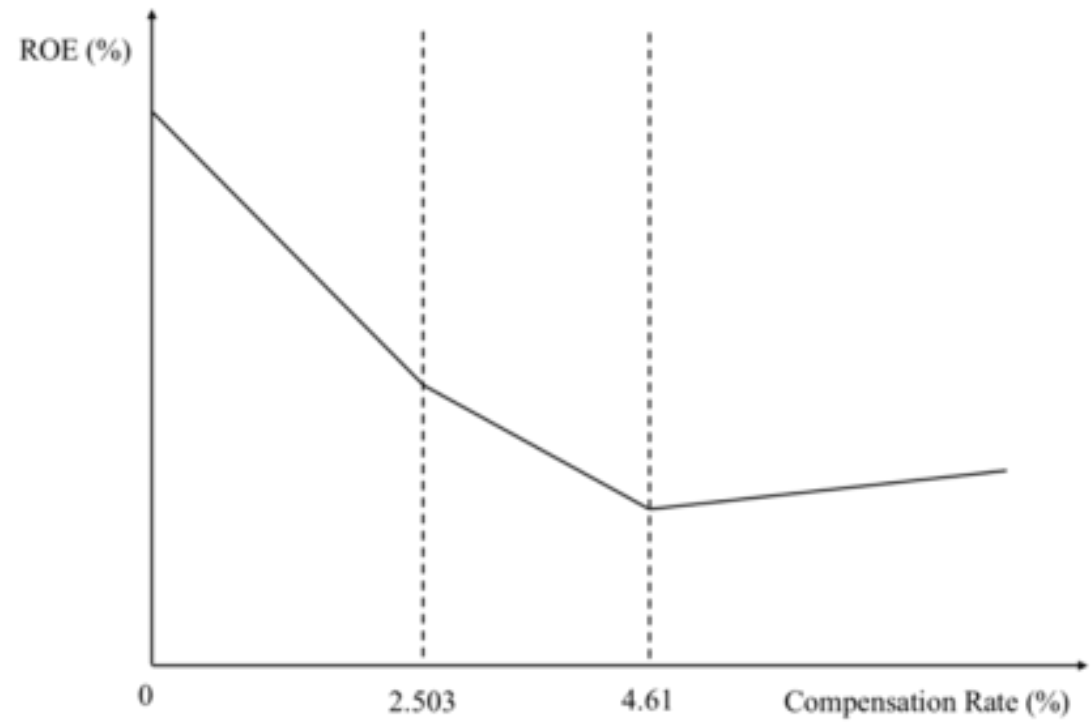

Figure 3. Compensation Rate and ROE

It can be intuitively observed that compensation rate is significantly negatively correlated with corporate performance if it is lower than the first threshold of $2.503 \%$. The coefficient of -8.667 implies that if life insurance companies set reimbursement in low positions, additional percent of compensation rate may incur a margin drop of $8.667 \%$ in corporate performance. If compensation rate is between $2.503 \%$ and $4.61 \%$, even though it is still negatively correlated with corporate performance, the curve becomes flatter. Once exceeding $4.61 \%$, reimbursement turns out to be positively related to corporate performance, indicating that high levels of compensation rate make clients who are impelled to purchase insurance with indemnity gain impressive proceeds. As a result, corporate performance of life insurance companies goes up.

\section{Conclusion and Policy Implications}

In conclusion, the life insurance industry in China is still an infant industry for the moment. On account of egregious progress, people's perception of life assurance has enhanced, giving rise to diversified demands. Undeniably, extensive management initially notches up a high growth rate and a large market share for life insurance companies when the market has just been exploited. Conversely, such a pattern is no longer fit for the current situation. At present, life insurance companies in China are at the crossroad of transition, which is solely in need of adjusting marketing channels in order to launch policy-oriented products that cater to the market.

Based on a panel data set of life insurance companies in China spanning from 2010 to 2014, this paper utilizes fixed effect model that controls heteroscedasticity and comprehensively analyzes the interaction between operational factors and corporate performance. Besides, how compensation rate affects corporate performance is also interpreted with the double threshold panel model. Empirical results find that in terms of marketing structure, a life insurance company which is a subsidiary of a bank, or affiliated to the same conglomerate (bancassurance), is a channel that possesses merits in costs. Bancassurance is thus capable of generating considerable rate of investment for stakeholders. By contrast, as for life insurance companies which lack such background, bancassurance and individual agent cannot significantly conduce to improvement of corporate performance. Likewise, the percentage of professional insurance agency is negatively related to corporate performance. Moreover, market structure and corporate assets are not determinants of corporate performance of life insurance companies. It is worth noting that the relation between compensation rate and corporate performance conforms to piecewise function rather than linear function or quadratic function.

Given that Chinese life insurance companies have certain merits in marketing structure, product structure and 
compensation rate, the following 5 policy implications are proposed to tackle such predicaments and to improve corporate performance.

Firstly, life insurance companies should reinforce the dominance of banks. It is imperative for life insurance companies which have certain relation with banks in capitals to make full use of such an inherent advantage. For example, accept capital injection from banks. Besides, sign a formal contract for exclusive sales agreement with banks that attaches the sales of life insurance products to the earnings of banks. Thereby, the superiority of banks, involving extraordinary reputation, considerable customer base and nationwide network, is able to be fully utilized. It is expected that bancassurance income may directly enhance the ROE of life insurance companies. However, as for insurance companies which have no relevance in capitals with banks, the barycenter of sales should be transferred to other channels, gradually reducing the dependence on bancassurance before ultimately abandoning that channel.

In addition, life insurance companies ought to exploit online channels that follow up the tendency of prevalent online finance and smart mobile phone terminal. The explosive growth of the life insurance industry in China is always driven by new marketing approaches. Nowadays, traditional channels such as bancassurance and individual agent fall into a recession whereas online channels are poised to be prosperous in the upcoming years. In comparison to traditional channels, online channels are far more convenient with more superior services, over which life insurance companies need to pander.

Apart from that, additional emphasis should be laid on indemnificatory insurance. According to the 2016 to 2010 Inclusion Finance Development Plan disclosed by the State Council of China, insurance products in principle that act the function of hedging risks should benefit the broad masses. Thus, life insurance companies in China are expected to spare no efforts to products with high security instead of high profitability, gradually attenuating the reliance on participating insurance. Chinese life assurance industry ought to proactively react to the call of government, making strategies align with national policies.

Furthermore, life insurance companies are supposed to diversify products to fulfill emerging needs in the market. In China, life assurance products are seriously homogeneous, $80 \%$ of which are participating insurance that cannot raise customers' willingness to buy. Therefore, life insurance companies, especially companies with small size, are not encouraged to expand the scale or to grab larger market share. Instead, introducing distinct products to target customers should be prioritized in order to improve customer loyalty. By doing so, naturally, the competitive advantage of life insurance companies is established.

Last but not least, the life insurance industry in China should increase compensation rate and relax restrictions on terms of reimbursement. Risk preferences of diverse customers are diametrically different, which implies disparity in the expectation of the amount of compensation obtained from insurance and in the willingness to pay for hedging risks. Thereby, high price and high reimbursement products can attract customers who are risk averse. Such type of customers has underlying demands for insurance as well as strong buying power. In general, the compensation rate of life insurance companies in China is extremely low, implying that only few clients can gain benefits. In the premise of attaining profits, Chinese life insurance companies can imitate developed countries in raising compensation rate aptly, for the purpose of appealing more customers. Consequently, sales may grow, which eventually contributes to enhancing corporate performance.

\section{References}

Alhassan, A. L., Addisson, G. K., \& Asamoah, M. E. (2015). Market Structure, Efficiency and Profitability of Insurance Companies in Ghana. International Journal of Emerging Markets, 10(4), 648-669. https://doi.org/10.1108/IJoEM-06-2014-0173

Fan, C. K. \& Cheng, C. W. (2009). An Efficiency Comparison of Direct and Indirect Channels in Taiwan Insurance Marketing. Direct Marketing an International Journal, 3(4), 343-359. https://doi.org/10.1108/17505930911000900

Hu, Q. (2011). Research on Problems of Bancassurance in China Based on the Pattern of Bank Insurance Agency. Master thesis, Lanzhou University, Lanzhou, China.

Jiang, C. \& Chen, S. (2015). Study on Correlation among Life Insurance Market Structure, Efficiency and Performance. China Soft Science, 2, 74-84. https://doi.org/10.3969/j.issn.1002-9753.2015.02.008

Kou, Y. (Eds.). (2010). Chinese Insurance Company Competitiveness Evaluation Research Report. China Culture and History Press, China.

Kweh, Q. L., Lu, W. M., Wang, W. K. \& Su M. H. (2014). Life Insurance Companies' Performance and Intellectual 
Capital: A Long-Term Perspective. International Journal of Information Technology \& Decision Making, 13(4), 755-777. https://doi.org/10.1142/S0219622014500588

Li, T. (2007). Study on the Competitiveness of Insurance Based on Panel Data Model, Master thesis, Hunan University, Hunan, China.

McKinsey \& Company (2012). Growth Under Uncertainty-Trends, Issues and Outlook of China's Life Industry. Mckinsey \& Company.

Shen, F. (2009). Influencing Factors of the Development of the Life Insurance Industry in China. Zhejiang Finance, 6, 52-53. https://doi.org/10.3969/j.issn.1005-0167.2009.06.029

Shi, J. \& Zhao, Z. (2003). Research on Core Competitiveness and Relevant Evaluation System of Life Insurance Companies. Modern Finance and Economics, 22-24. https://doi.org/10.3969/j.issn.1005-1007.2003.08.005

Wang, X. \& Peng, X. (2011). An Analysis of Impacts of Ownership Structure on Corporate Performance of Chinese Listed Life Insurance Companies. Accounting Society of China, Beijing, China.

Wassink, B. K., Castagnetta, A. \& Metz, S. (2015). Life Insurance Distribution at A Crossroad, EY, New York, U.S.

Yu, J. (2005). A Positivistic Analysis of Corporate Performance of Life Insurance Companies. Journal of SWUPL, 7(2), 54-57. https://doi.org/10.3969/j.issn.1008-4355.2005.02.010 